\title{
Dylematy nauczania etyki w środowisku szkolnym
}

W perspektywie refleksji nad stanem etyki w Polsce zasadnym wydaje się rozważenie kwestii jej nauczania $w$ warunkach polskiej szkoły ponadpodstawowej. Edukacja etyczna jest bowiem nieodzownym elementem wychowania, problem jednak leży w tym, że dotychczas jest ona traktowana po macoszemu. Realizowana jest w ramach tradycyjnej struktury nauczania, uwzględniającej godziny wychowawcze, od pewnego czasu także w ramach godzin religii. Elementy wychowania etycznego pojawiają się zapewne przy okazji nauczania różnych przedmiotów humanistycznych. Jest to jednak edukacja wysoce niezadowalająca, nie mogąca dostarczyć wystarczającej wiedzy w tej tak ważnej wszak dziedzinie. W efekcie tego młodzi ludzie w Polsce prezentują niepokojącą ignorancję nawet w najbardziej podstawowych zagadnieniach etycznych (normy i ich uzasadnienie, wartości moralne, odpowiedzialność za wolny wybór, sumienie....) $)^{1}$. Przekłada się to także na brak ugruntowanej świadomości dotyczącej zagadnień etyki środowiska.

Taki stan rzeczy wymusza konieczność gruntownej refleksji na temat stanu edukacji etycznej w szkołach polskich. W szkole ponadpodstawowej bowiem rozpoczyna się w uczniach proces dojrzewania do odpowiedzialnych wyborów etycznych. Jeśli nie otrzymają oni w tym czasie rzetelnego ugruntowania teoretycznego, wybory te będą podyktowane czynnikami pozaracjonalnymi.

W polskich warunkach edukacyjnych nauczanie etyki rozpoczyna się stosunkowo późno i dokonuje się w specyficznym klimacie. Ma on związek z uwarunkowaniami historyczno-ideologicznymi, jak i z ekonomicznymi.

W szkole podstawowej etyka jest właściwie nauczana w ramach lekcji religii - jako etyka religijna. W szkole ponadpodstawowej i ponadgimnazjalnej zagadnienia etyczne mogą być rozpatrywane w ramach jakiejś podstawowej edukacji filozoficznej, jeśli taka jest prowadzona, co, do tej pory, jest zjawiskiem bardzo

\footnotetext{
Ta pesymistyczna diagnoza nie określa praktyki, to znaczy abstrahuje od tego, jakimi postawami w praktyce cechuje się dzisiejsza młodzież, ale dotyczy stanu teoretycznej świadomości tych podstawowych zagadnień. Nie chodzi więc o to, czy młodzież polska jest dostatecznie wychowana do realizacji zadań etycznych, ale ile na ten temat wie.
} 
rzadkim. Równie rzadka jest realizacja postulatu ustawy o wprowadzeniu nauczania religii w szkole, które przewiduje, że dla uczniów nie uczęszczających na lekcje religii powinny być zorganizowane zajęcia z etyki. Fakt, że procent nie uczęszczających na lekcje religii jest znikomy, ze brak jest odpowiedniej kadry oraz funduszy na nią powoduje, że w praktyce postulat ten nie jest realizowany. W efekcie uczeń szkoły ponadpodstawowej ma niewielki dostęp do teoretycznych zagadnień związanych z etyką.

W ramach studiów, o ile nie są to studia systematyczne nad sama etyką, filozofia moralności pojawia się w ramach ogólnego nauczania filozofii, albo czasem (np. w studiach pedagogicznych) jako odrębna dyscyplina ( $\mathrm{z}$ reguły $\mathrm{w}$ niewielkim wymiarze godzin).

Taki stan rzeczy czyni zrozumiałym fakt poważnych braków istniejących w edukacji etycznej w warunkach polskich. Dlatego już na początku naszych rozważań nie jest bezzasadnym sformułowanie postulatu wobec całego systemu edukacyjnego w Polsce, o zwiększenie wymiaru godzin nauczania etyki tak w szkołach ponadpodstawowych, jak i w szkołach wyższych ${ }^{2}$.

Obecność etyki w nauczaniu szkolnym i akademickim, bez względu na to, czy jest ona wystarczająca, czy nie, wiąże się z koniecznością wyboru określonego sposobu jej wykładu. Temu zagadnieniu poświęcone są niniejsze rozważania. Ich celem będzie nie tyle zagadnienie metodyki nauczania etyki, co raczej próba analizy o charakterze bardziej filozoficznym, ściślej - metaetycznym. Zasadną bowiem wydaje się refleksja nad teoretycznym aspektem nauczania etyki: jakiego typu etyka jest nauczana, jaka powinna być nauczana, biorąc pod uwage specyfikę środowiska szkolnego. Nie chodzi przy tym jednak o zagadnienia metodyki nauczania etyki, ale o sposób prezentacji zagadnień etycznych.

\section{Typologia form nauczania etyki}

Rozważenie tego, jak etyka ma być prezentowana w nauczaniu wymaga przeprowadzenia wstępnej typologii możliwych sposobów jej prezentacji w ramach zajęć szkolnych $w$ aspekcie zawartych $w$ niej treści etycznych. Z takiego punktu widzenia (metaetycznego) proponuje się wyodrębnienie dwóch najogólniejszych typów nauczania etyki: „neutralistyczne” (bardziej opisowe) i „zaangażowane” (bardziej normatywne).

Neutralistyczny sposób uczenia etyki polega na krytycznej prezentacji różnych systemów etycznych bez angażowania się w ich wartościowanie. Prowadzący zajęcia przyjmuje „neutralny”, niezaangażowany w żaden system, metaetyczny

2 Z tym wiąże się konieczność lepszej edukacji filozoficznej w ogóle, o czym jeszcze będzie mowa poniżej. 
punkt widzenia, referując jedynie różne systemy etyczne, czego celem jest ich krytyczny opis. Tak prezentowana etyka będzie właściwie przeglądową historią etyki.

Zaangażowany sposób prezentacji teorii etycznych dokonuje również prezentacji systemów etycznych, ale ocenia krytycznie ich adekwatność w opisie i wyjaśnianiu zagadnień etycznych. Krytyka ta odwołuje się do argumentów racjonalnych i przez to tak prezentowana etyka będzie miała charakter bardziej analityczny, refleksyjny.

Wskazanie na najogólniejsze typy nauczania etyki nie przekreśla możliwości istnienia rozwiązań pośrednich (dlatego rozróżnienia niniejsze mają charakter typologii, a nie podziału zupełnego), zawierających oba typy w różnych „proporcjach". W rozważaniach niniejszych uwzględnione będą jednak jedynie oba typy W „czystej postaci”, dla możliwie przejrzystego wskazania różnic między nimi.

Obrońca neutralistycznego sposobu wykładu etyki może przytoczyć szereg racji za swoim punktem widzenia.

Neutralistyczna postawa zdaje się być wygodniejsza dla uczącego, bo pozwala zachować mu dla siebie swoje przekonania, ograniczając się do referowania różnych stanowisk etycznych na przestrzeni dziejów.

Taka postawa odpowiada, modnej dzisiaj, postmodernistycznej krytyce kultury współczesnej. Krytyka ta ma wiele źródeł. Z punktu widzenia refleksji nad moralnością była ona przygotowana przez pozytywistyczną koncepcję etyki. $\mathrm{W}$ polskich realiach przejawiało się to w propagowaniu emotywistycznego podejścia do zagadnień etycznych (bronionego przez prof. M. Ossowską i cały szereg jej uczniów), w którym odmawia się normom i ocenom etycznym waloru obiektywności i traktuje się je jedynie jako narzędzie wyrażania subiektywnych postaw emocjonalnych ${ }^{3}$. $Z$ drugiej strony coraz bardziej popularne stają się idee głoszone przez postmodernistów, oznajmiające zmierzch tzw. wielkich narracji, albo meta-narracji (czyli dla etyki: absolutystycznych systemów moralnych) i zastąpienie ich „mikro-narracjami” (J.F. Lyotard), "grami kulturowymi” (R.Rorty), czy „mikrologiami” (T. Adorno), które będą wybierane nie na podstawie racjonalnej przewagi którejkolwiek z nich, ale na mocy nieskrępowanej wolności ${ }^{4}$. Zaangażowanie się zatem w jakiś system moralny ma mieć charakter wejścia w określoną "grę kulturową," której wartość i obowiązywalność jest ograniczona zakresem tej „gry” i nie rości sobie pretensji do krytyki innej "gry", którą wybierze ktoś inny. Ma to uchronić kulturę, a w szczególności moralność, przed błędem „centryzmu”, z którego wynikać mają: totalitaryzm, nietolerancja i dalsze grzechy przeciw pluralizmowi ${ }^{5}$.

T. STYCZEŃ, Wprowadzenie do etyki, Lublin 1993, s. 273.

4 H. Kiereś, Trzy socjalizmy. Tradycja tacińska wobec modernizmu i postmodernizmu, Lublin 2000, s. 17-18.

5 Tamże, s. 19. 
W Polsce rzecznikiem takiej postmodernistycznej etyki jest Z. Bauman ${ }^{6}$. Nie tylko dokonuje on krytyki tradycyjnej etyki, ale postuluje odrzucenie etyki na rzecz nieskrępowanej moralności, opartej na indywidualnej wolności jednostki. Jego zdaniem cywilizacja współczesna nie potrzebuje już żadnego prawodawstwa etycznego, co „nie musi oznaczać zmierzchu moralności”7. Ma to być jednak moralność wolna od zasad uniwersalnych, gruntowanych przez filozoficzną refleksję etyczną.

W tej perspektywie może się wydawać, że postawa neutralistyczna w prezentacji różnych stanowisk etycznych lepiej wychowa do tolerancji, poszanowania innych stanowisk, kultur i obyczajów.

Nie bez znaczenia jest również zarzut, że zaangażowany typ wykładu prowadzić będzie do niepotrzebnego moralizatorstwa i ideologizacji procesu nauczania etyki. Etyka, jeśli ma być obiektywna powinna być niezależna.

Te argumenty można przytoczyć na obronę stanowiska neutralistycznego. Czy jednak są one wystarczające? Aby to rozważyć, trzeba najpierw zdać sobie sprawę z zadań, jakie nauczanie etyki ma do spełnienia w środowisku szkolnym (i akademickim). W ich perspektywie właśnie trzeba rozważyć przydatność obu wyżej wzmiankowanych sposobów prezentowania materiału etycznego.

\section{Nauczanie etyki w perspektywie zadań jej stawianych}

\section{a. Racjonalizacja wyborów moralnych}

Zasadniczym teoretycznym zadaniem edukacji etycznej wydaje się być uczenie racjonalnych uzasadnień dla dokonywanych wyborów etycznych ${ }^{8}$. Celem kształcenia etycznego powinno być wzbudzenie w uczniu potrzeby życia (działania) racjonalnie uzasadnionego oraz dostarczenie mu odpowiedniej argumentacji. Problemem jest jednak fakt, że nie ma zgody wśród filozofów, czy takie racjonalne uzasadnienie zachowań etycznych jest możliwe. Kwestionuje to wszak wspominana powyżej pozytywistyczna i postmodernistyczna krytyka etyki.

Niezaangażowany sposób prezentacji etyki współbrzmi z krytyczną oceną możliwości ludzkiego umysłu w sferze uzasadnień wyborów moralnych. Ten sposób wykładu może zatem wyrobić w uczniu przekonanie, że sprawa wyboru określonego sposobu życia i płynących stąd konkretnych wyborów moralnych, nie zależy od nakazów rozumu, ale kształtuje się w innych pozaracjonalnych płaszczyznach: w sferze emocji, gustów, upodobań, wierzeń, ale także ideologii. Taki zatem sposób uczenia etyki, w sposób niejako programowy, nie daje wychowankowi racjonalnego narzędzia do podejmowania odpowiedzialnego życia moralnego. Ugruntowuje

Zob. Z. Bauman, Dwa szkice o moralności ponowoczesnej, Warszawa 1994.

Z. BaUman, Dwa szkice..., s. 75 
raczej postawy irracjonalne $w$ tak istotnej sferze życia człowieka. Jest to być może bardzo modne w perspektywie wspominanej postmodernistycznej krytyki kultury współczesnej, ale jednocześnie stanowi wyraźny przejaw kryzysu zaufania do rozumu, charakterystyczny dla czasów dzisiejszych.

$\mathrm{W}$ tej perspektywie ograniczenie się, w wykładzie etyki, jedynie do prezentacji palety rozwiązań etycznych przy dzisiejszym stanie kultury w ogóle, a poziomu świadomości moralnej w szczególności, wydaje się wręcz szkodliwa. Skutkiem takiego nauczania jest wzbudzenie w uczniu przekonania, że istnieje wiele konkurencyjnych, "równosilnych” wzorców zachowań moralnych. Tymczasem problemem czasów dzisiejszych nie jest brak wzorców, ale raczej ich nadmiar przy braku świadomości, jakimi kryteriami trzeba się posługiwać w ich wyborze ${ }^{9}$. Neutralistyczne nastawienie w prezentacji etyki wpisuje się więc w fałszywy i archaiczny obraz szkoły, jako miejsca wyłącznie edukacji intelektualnej z pominięciem czynnika wychowawczego. Tymczasem nauczanie etyki ma być wprowadzone, jak można przypuszczać, nie tyle, by informować o dawnych i obecnych systemach etycznych, ale jako istotny czynnik wspomagający szkolny wysiłek wychowania moralnego ${ }^{10}$. Etyka, nauczana w „neutralny” sposób, nie będzie żadnym wprowadzeniem w odpowiedzialność wobec świata wartości, ale szybko stanie się jeszcze jednym przedmiotem, którego treści trzeba będzie się starannie wyuczyć i jak najszybciej zapomnieć.

\section{b. Racjonalizacja czy ideologizacja?}

Czy jednak „zaangażowany” sposób prezentacji treści etycznych nie będzie prowadził do ideologizacji tych treści i czy nie wzbudzi w uczniach postaw fanatycznych i nietolerancyjnych? Przed takimi postawami na wszak chronić nauczanie etyki w szkole ${ }^{11}$.

Obronę etyki „zaangażowanej” należy zacząć od stwierdzenia, że nie tyle chodzi tutaj o nauczanie konkretnego systemu moralnego, co raczej o wyrobienie właściwej postawy wobec różnych systemów moralnych. Postawa ta nie polega na negowaniu wielości kultur i związanych z nimi systemów etycznych, ale na

8 Na ten aspekt nauczania etyki wskazują podstawy programowe dotyczących nauczania filozofii w szkole, opracowane przez MEN. Czytamy w nich, że kształcenie filozoficzne (a w tym etyczne) ma za zadanie „utwierdzanie w uczniu poczucia własnej podmiotowości, analizowania i oceniania zjawisk społecznych oraz dokonywania wyboru wartości”. Cyt. za R. JADCZAK, Etyka w szkole - uczyć myśleć i dziatać odpowiedzialnie, w: Z. Sareło (red), Etyka w szkole, Warszawa 1997, s. 23.

9 M. Szulakiewicz, Kulturowe i filozoficzne uwarunkowania etyki w szkole, w: Z. Sareło (red), Etyka w szkole, Warszawa 1997, s. 49-50.

10 Tamże, s.46-49.

11 Jednym $z$ zadań stawianych filozofii (a w szczególności także etyce) w szkole przez podstawy programowe MEN jest nauczenie umiejętności „przezwyciężania stereotypów, fanatyzmu i nietolerancji”. Cyt. za R.JADCZAK, Etyka w szkole, s. 23. 
ich racjonalnej analizie. Nawiązuje ona do ideału, który można nazwać „klasycznym" w znaczeniu postawy, ugruntowanej przez kulturę grecko-łacińską. Wszak starożytni Grecy, lepiej niż ktokolwiek, zdawali sobie sprawę z wielości kultur, wielości rodzajów praw życia społecznego i leżących u ich podstaw różnorodności zapatrywań moralnych. Nie przeszkadzało to im jednak w podjęciu racjonalnej krytyki tych stanowisk właśnie po to, by różne systemy moralne oceniać nie w świetle irracjonalnych uprzedzeń, ale przez odwołanie się do założeń racjonalnych $^{12}$. Zatem nie można mylić etyki z moralizatorstwem. Zadaniem etyki nie jest bowiem przekonywanie do jakiejś moralności, ale poszukiwanie racjonalnych podstaw pod ludzkie działania moralne. To, co etyka, nauczana w szkole, ma dać młodemu człowiekowi to nie chaotyczny zestaw różnych (często wzajemnie sprzecznych) poglądów etycznych, ale racjonalne narzędzie ich oceny ${ }^{13}$.

\section{c. Racjonalizacja a niezależność etyki}

Czy jednak nauczanie zaangażowane etyki nie zagrozi jej niezależności?

Wydaje się, że postulat niezależności etyki opiera się na pewnym nieporozumieniu, mającym swoje źródło w historyczno-ideologicznych uwarunkowaniach współczesnej dyskusji etycznej w Polsce. W perspektywie dawnej dyskusji światopoglądowej, rozgrywającej się w epoce realnego socjalizmu, przez etykę niezależną rozumiano etykę wolną od założeń religijnych, ściślej (w polskim kontekście) - założeń chrześcijańskich. Tak rozumiana etyka wpisywała się często w klimat toczonej wtedy wojny ideologicznej między ideologią marksistowską a chrześcijaństwem. Zakładano przy tym, że etyka zawsze jest zależna od jakiejś ideologii (jest bowiem zawsze wyrazem poglądów jakiejś klasy społecznej), a „ideologia” chrześcijańska jest "nienaukowa” i powinna być zastąpiona ideologią „naukową", najlepiej marksistowską ${ }^{14}$.

Niezależność etyki może być dobrym postulatem do jej nauczania w szkole i na uczelni pod warunkiem, że pojmie się ją jako niezależność nie tylko (nie tyle) od religii, co od wszelkiej ideologii ${ }^{15}$.Prawdziwą niezależność od ideologii uzyska

12 R. Spaemann, Podstawowe pojecia moralne, Lublin 2000, s. 9-10

13 Zarzut moralizatorstwa często stawiany jest tradycyjnej etyce przez zwolenników jej ponowoczesnej krytyki. Jak się zdaje opiera się on na nieporozumieniu, co do natury samej etyki. Postmoderniści w swych atakach zapominają, że celem etyki nie jest przekonywanie do określonej moralności, ale znalezienie racjonalnych podstaw do odpowiedzi na pytanie o to, co człowiek powinien i dlaczego. Zob. na ten temat R.WIŚNIEWski, Jakiej etyki potrzebujemy? W sprawie uproszczeń postmodernistycznej krytyki etyki, w: Z. Sareło (red), Moralność i etyka w ponowoczesności, Warszawa 1996, s. 86-7.

14 Gwoli sprawiedliwości należy zaznaczyć, że postulat etyki niezależnej w czasach PRL-u był formułowany nie tylko w środowiskach marksistów. Do dyskusji nad jego obroną włączyli się także wybitni myśliciele z innych kręgów, jak choćby T. Kotarbiński czy T. Czeżowski. Zob. T. STYczé́, Wprowadzenie do etyki, s. 43-45.

15 Złagodzenie, czy nawet zniesienie, opozycji między etyką religijną a etyką niezależną należy rozumieć w tym znaczeniu, że nie w ramach etyki niezależnej nie będzie apriorycznie zakładać się 
etyka dopiero wtedy, gdy powróci na swe tradycyjne tory - zależności jedynie od swych filozoficznych podstaw: od metafizyki (teorii rzeczywistości) i filozofii człowieka ${ }^{16}$. Niezależność etyki może być zrealizowana wtedy, gdy będzie ona traktowana jako fragment wiedzy filozoficznej, neutralnej światopoglądowo (ideologicznie). Można zatem powiedzieć, że źródłem niezależności etyki, nauczanej w szkole, nie jest jej programowa opozycyjność (często wrogość) wobec etyki religijnej, ale ugruntowanie jej w rzetelnej wiedzy filozoficznej. Nauczanie etyki filozoficznej domaga się zatem odpowiedniej edukacji filozoficznej, bez której nie jest ono możliwe. Edukacja taka powinna rozpoczynać się jak najwcześniej - w gimnazjum, albo nawet w szkole podstawowej. Pozwala ona na lepsze zrozumienie przez ucznia filozoficznych źródeł i uwarunkowań różnych systemów etycznych. Prezentacja szczegółowego programu takiej edukacji wykracza poza ramy niniejszego opracowania, można powiedzieć tylko ogólnie, że chodziłoby o nauczanie historii myśli filozoficznej, jako odpowiedzi na egzystencjalne pytania, rodzące się już, a może przede wszystkim, u dzieci. System edukacyjny, który nie uwzględnia wymiaru filozoficznego, prowadzi do zabicia tych pytań lub odpowiedzi niepelnych ${ }^{17}$.

Nauczanie etyki zaangażowane nie oznacza zatem nauczania etyki uwikłanej ideologicznie, ale nauczanie etyki filozoficznej. Niestety wydaje się, że w założeniach co do nauczania etyki w szkole trwają nadal echa wspominanej wojny światopoglądowej mimo zmiany warunków społeczno-politycznych. Wydaje się bowiem, że potraktowanie etyki jako przedmiotu alternatywnego dla katechezy religijnej - co znalazło wyraz w ustawie o nauczaniu religii w szkole - jest dalekim echem tej wojny, niezależnie od tego, czy taka była intencja prawodawcy. Powoduje to traktowanie nauczania etyki jako „zagospodarowania” czasu dla tych uczniów, którzy nie chcą uczęszczać na lekcje religii. W ten sposób utrwalają się fałszywe stereotypy przeciwstawności religii (etyki religijnej) i wiedzy (etyki „niezależnej”) utrudniające, albo wręcz uniemożliwiające rzetelne poszukiwania etyczne oraz powodujące zamęt w głowach i sumieniach uczniów ${ }^{18}$.

opozycji i konkurencyjności względem etyki religijnej. Nie trzeba chyba specjalnie dowodzić, że etyka chrześcijańska, a przynajmniej katolicka, czerpie bardzo wiele z etyki filozoficznej, jej konkluzje nie muszą zatem być uznawane za sprzeczne $z$ konkluzjami etyki niezależnej.

16 Por. T. Ślipko, Zarys etyki ogólnej, Kraków 2002³ , s. 38-39.

17 Warto nadmienić, że podstawy systemu edukacyjnego dla szkół podstawowych, opartego na szeroko rozumianej filozofii, opracowano w Stanach Zjednoczonych w latach siedemdziesiątych XX w. jako uzupełnienie do powszechnej tam edukacji filozoficznej na poziomie szkół gimnazjalnych (zob. M. Lipman, A.M. Sharp, F.S. Oscanyan, Filozofia w szkole, Warszawa 1996). W Polsce powszechne nauczanie filozofii nawet na poziomie szkoly ponadgimnazjalnej, jest wciąż jedynie postulatem. Zob. K. Olbrycht, Odpowiedzialność pedagoga w nauczaniu etyki, w: Z. Sareto (red), Etyka w szkole, Warszawa 1997, s. 75-77.

18 K.Olbrycht, Odpowiedzialność pedagoga...., s. 74. 
Traktowanie etyki jako alternatywy dla religii jest szkodliwe także z innych względów.

Etyka religijna jest etyką zaangażowaną światopoglądowo. Sposób uzasadnień jej tez różni się od stosowanego w filozofii moralności - religia wszak opiera się na wierze. Jeśli uczeń ma dostęp jedynie do tego typu etyki, do tego typu uzasadnień, może w sobie wyrobić przekonanie, że uzasadnienia etyczne są tylko typu wierzeniowego, nie ma zatem dyskusji między różnymi etykami religijnymi.

Traktowanie etyki i religii jako alternatywnych dziedzin dotyczących moralności może zrodzić przekonanie szkodliwe dla samego nauczania religii: że religia sprowadza się do pewnych zachowań etycznych, że religia jest pewną formą moralności. Jest to niestety dość powszechny błąd naszej potocznej świadomości religijnej, nie ma jednak powodu, by utrwalać go poprzez niezręczne posunięcia edukacyjne.

W tej perspektywie trzeba postulować konieczność nauczania etyki filozoficznej, która objęłaby ogół uczniów, nie tylko tych, którzy nie uczęszczają na lekcje religii. Etyka taka jest potrzebna wszystkim uczniom tak wierzącym, jak i niewierzącym.

\section{d. Wychowanie do tolerancji}

Innym zagadnieniem związanym z nauczaniem etyki jest kwestia wychowania do postaw tolerancyjnych. Sam problem tolerancji jest złożonym problemem filozoficznym, także etycznym. Jego wyczerpująca prezentacja przekracza ramy niniejszego rozważania. Dla naszych potrzeb wystarczy zauważyć, że pojęcie tolerancji jest zawsze uwikłane w system etyczny, a nawet, co dla nas istotniejsze - metaetyczny. Wraz z postmodernistyczną krytyką kultury w ogóle, a etyki w szczególności, utrwala się bowiem w świadomości społecznej pojmowanie tolerancji jako życzliwej akceptacji każdej odmienności. Postawa takiej życzliwości współbrzmi z ponowoczesnymi postulatami pluralizmu w kulturze, a w szczególności w etyce.

Do takiego właśnie pluralizmu zdaje się wychowywać neutralistyczny wykład etyki w szkole. Co nauczy go lepiej jeśli nie życzliwa (choć krytyczna) prezentacja różnych odmiennych względem siebie stanowisk etycznych? W podejściu takim jest jednak pewien zasadniczy problem - kwestia granic tak pojętej tolerancji. Przyjmując neutralistyczny punkt widzenia, trudno będzie wytłumaczyć uczniowi dlaczego właściwie nie akceptujemy pewnych rozwiązań: społecznych (na przykład nazizmu), kulturowych, czy etycznych (na przykład postaw nietolerancji). Trzeba będzie odwoływać się do mętnych argumentów postępu, demokracji, czy walki z ciemnotą. Nie będzie to jednak stanowić rzetelnej argumentacji etycznej, ale raczej żonglerkę epitetami, przywołującą na powrót do życia uśpione demony przeszłości (wedle jakich kryterium bowiem zdefiniować postęp, wstecznictwo, ciemnotę). W ten sposób łatwiej w gruncie rzeczy będzie o postawę nietolerancji i utrwalanie fałszywych stereotypów. 
W kwestii tolerancji widać wyraźnie konieczność racjonalnego ugruntowania naszych postaw i ocen moralnych. Tolerancja nie może polegać na bezmyślnej akceptacji jakiegokolwiek stanowiska, wręcz przeciwnie - zakłada ona, że wskutek racjonalnej krytyki uznaje się pewne stanowiska za błędne, ale z jakichś innych, wyższych racji się je znosi (lac. tolero - cierpliwie znoszę, wytrzymuję). Konsekwencją właściwie pojętej tolerancji jest uznanie, że istnieją stanowiska wobec których nie może być tolerancji (nie ma racji, by je znosić), a rzeczą racjonalnego namysłu jest wskazać racje za tolerowaniem czegoś i przeciw tolerowaniu czegoś.

\section{e. Umiejętność oceniania i wybierania wartości}

Podstawy programowe do nauczania filozofii w szkole wskazują również na kwestię umiejętności wybierania dóbr-wartości. Umiejętność ta jest ściśle powiązana ze zdolnością racjonalnej analizy zachowań moralnych.

Procedura wskazywania na realne stany rzeczywistości, które są wartością (domagają się naszej ochrony) powinna opierać się na racjonalnym uzasadnieniu ich wartościowego charakteru i wskazywaniu powinności stąd wynikających. Trudność polega na tym, że nie ma zgody wśród etyków co do tego, co jest dobre. Podstawowa linia podziału biegnie między etykami absolutystycznymi, uznającymi niepodważalność pewnych wartości, a etykami relatywistycznymi, uzależniającymi wartości od czegoś bardziej podstawowego (przyjemności, korzyści, opłacalności)$^{19}$. Oba typy etyk mają na swoje uzasadnienie argumenty roszczące sobie pretensje do prawdziwości, zatem racjonalizacja postaw moralnych powinna polegać także na rzetelnej prezentacji tych argumentów. Każdy z tych typów posiada także pewne walory edukacyjne i wychowawcze, każdy też niesie ze sobą pewne zagrożenia.

Etyka typu absolutystycznego broni przekonania, że istnieje jeden podstawowy system wartości, do którego respektowania zobowiązany jest każdy człowiek. Ów system wartości rodzi w człowieku zestaw powinności o charakterze bezwzględnym i kategoryczny imperatyw ich realizowania. Etyka tego typu będzie dobrze sprawdzać się w wychowywaniu postaw heroicznych, ofiarnych, bezkompromisowych. Bezwzględność bowiem pewnych wartości rodzi nakaz ich realizowania bez oglądania się na cenę, jaką przyjdzie za nie zapłacić. Trudnością takiej etyki jest jednak ustalenie listy absolutnych wartości, które należy realizować oraz wynikający stąd dogmatyzm, który może prowadzić do wykształcenia się mentalności totalitarnej.

Etyki relatywistyczne nie uznają żadnej obiektywnej hierarchii wartości, a wybieranie czegoś uzależniają od różnie pojmowanego dobra: jako przyjemności (etyka hedonistyczna), korzyści (etyka utylitarystyczna). W nauczaniu tak pojmowanej etyki bardziej wyakcentowana będzie wolność wyboru i poszanowanie wyboru innych, co nie jest bez znaczenia dla umiejętności życia w plura-

19 R.H. Popkin, A. Stroll, Filozofia, Poznań 1994, s. 73-4. 
listycznym społeczeństwie. Słabością takiej etyki jest niemożność dostatecznego uzasadnienia postaw heroicznych, ofiarnych oraz kształtowanie przekonania, że dobre jest wszystko to, co wolnie wybrane (co w konsekwencji może prowadzić do całkowitego odrzucenia norm moralnych ${ }^{20}$.

Dodatnie i ujemne strony obu tych etyk powinny zostać jakoś ukazane w ramach nauczania etyki. Tutaj zajęcie postawy neutralistycznej jest pozornie bardziej adekwatne. Pozwala ono wszak analizować różne stanowiska z neutralnego punktu widzenia. Niesie ono w sobie jednak pewna słabość, wskazywana już w innym aspekcie. Trudno będzie uczniowi nabyć umiejętności dokonywania wyborów dóbr-wartości, jeśli wskutek nauczania etyki będzie miał świadomość, że istnieje wiele „równosilnych" koncepcji tego co jest dobre (wartościowe). Przy takiej świadomości etycznej uczeń nabierze raczej przekonania, że każdy wybór moralny jest dobry lub że wybór ten może być dokonany na innych niż racjonalne podstawach.

\section{f. Wychowanie do odpowiedzialności}

Kwestia umiejętności wybierania wartości jest o tyle ważna, że wiąże się z zagadnieniem zdobywania postaw odpowiedzialnych ${ }^{21}$. Rozumieć przez to należy tak ponoszenie, jak i podejmowanie odpowiedzialności za $\cos ^{22}$. Wiąże się to $\mathrm{z}$ wyrobieniem w sobie świadomości tego, że realizacja świadomie wybranej wartości niesie ze sobą powstawanie realnych zmian w samym działającym, jak i w jego otoczeniu. Wbrew lansowanym przez niektóre media i pseudoautorytety tezom wykład etyki powinien wyraźnie uświadomić uczniowi, że kwestia jego decyzji związanej z wyborem wartości nie jest błahostką: to, co on wybiera i to, co w związku z tym czyni ma realny wpływ na jego ( $\mathrm{i}$ nie tylko jego) „dzis” $\mathrm{i}$,jutro”.

\section{g. Wychowanie ekologiczne}

W perspektywie uczenia postaw odpowiedzialnych jawi się kolejne bardzo ważne zagadnienie. Współczesna etyka coraz wyraźniej akcentuje sprawę relacji człowieka nie tylko ze środowiskiem ludzkim, ale i pozaludzkim, wobec coraz lepszego rozumienia interakcji, jakie zachodzą między człowiekiem a jego, szeroko rozumianym, środowiskiem. Chodzi tu tak o świat przyrody i związaną z nim kwestię zagrożeń ekologicznych, jaki i świat wytworów człowieka, które nie są już prostymi narzędziami, ale zdobywają swoistą autonomię wobec swego twórcy i często są również jego zagrożeniem. Dziś nie można pomijać, ani lekceważyć tych zagadnień, także w nauczaniu etyki w szkole.

Neutralistyczny wykład zagadnień etycznych nie wydaje się być adekwatnym sposobem do wyrobienia takich postaw wśród młodych ludzi, które podnosiłyby ich poziom świadomości ekologicznej. Przeniesienie istoty dyskusji etycznej do

${ }^{20}$ M. Szulakiewicz, Kulturowe i filozoficzne uwarunkowania...., s. 43-45 
sfery pozaracjonalnej ( co jest konsekwencją neutralistycznego wykładu) spowoduje, że ważne kwestie ludzkich odniesień tak do świata osób, jak i do całej przyrody, będą sprowadzone do ukształtowania emocjonalnych jedynie postaw wobec środowiska życia czlowieka (opartych na mglistym postulacie „sympatii” do środowiska) bez ich należytego racjonalnego ugruntowania. Nie sposób dogmatycznie stwierdzić, że mamy szanować przyrodę bez wskazywania powodów, dla których mamy to czynić. Nasz szacunek dla przyrody i jego ugruntowanie w odpowiedniej moralności, nie może sprowadzać się do kwestii mody, upodobań, czy sympatii.

Postawa odpowiedzialności za środowiska powinna być zatem ukształtowana przez etykę, która uczy racjonalnych uzasadnień dla ludzkich działań moralnych. Aby nauczyć się takiej postawy, nie wystarczy zatem wzbudzanie do niego sympatii, ale potrzebne jest:

- ukazanie, że istnieją niezbywalne (absolutne) dobra-wartości związane z tym środowiskiem, których ochrona jest naszą powinnością (wychowanie do dostrzegania wartości ${ }^{23}$

- ukazanie realnych konsekwencji naszych działań w środowisku w perspektywie tych wartości (wychowanie do odpowiedzialności)

- uzasadnienie konieczności kształtowania trwałych postaw moralnych wynikłych z poczucia odpowiedzialności za wartości środowiskowe, które należy chronić (wychowanie cnót moralnych).

Na wszystkich tych poziomach działania etyczno-wychowawczego wydaje się niezbędnym, aby etyka, która ma na tych poziomach działać, była zaangażowana.

\section{Zakończenie}

Zrealizowanie powyżej zarysowanych zamierzeń w realiach polskiej szkoły jest na pewno bardzo trudne $z$ uwagi przede wszystkim na fakt bardzo ograniczonych ram czasowych, jak i zastraszająco nikłej wiedzy filozoficznej uczniów.

21 Podstawy programowe MEN do nauczania filozofii formułuja to jako „ukształtowanie aktywnej postawy wobec świata opartej na wrażliwości moralnej, poczuciu odpowiedzialności za los własny i innych ludzi”. Cyt. za: R. JADZCAK, Etyka w szkole, s. 23

22 Zob. R. Ingarden, Ksiązeczka o człowieku, Kraków 1973, s. 78

23 W kształtowaniu postawy odpowiedzialności za swoje czyny w perspektywie ekologicznej wydaje się, że bardziej przekonujące są propozycje etyki absolutystycznej. Bez względu na to, czy będziemy mówić o obiektywnych wartościach, czy o realnych dobrach-celach naszych działań, mamy do czynienia z postulatem uwzględnienia realnej, ontycznej struktury rzeczywistości, która domaga się od człowieka jej uszanowania. Problemy ekologiczne, które uświadamiamy sobie dzisiaj, jak nigdy dotąd, są bardzo przekonującym argumentem za tym, że brak szacunku dla tego, czym rzeczywistość faktycznie jest, kończy się źle dla człowieka. 
W praktyce więc najczęściej prezentowana jest zwięzła historia etyki i, co najwyżej, podstawowy słownik pojęć etycznych. W rezultacie to właśnie neutralistyczny sposób prezentacji etyki przeważa w praktyce jej nauczania w szkole. Nie zawsze jest to efekt w pełni uświadomionego wyboru dokonanego przez nauczyciela, ale raczej efekt niemożności zrealizowania wszystkiego w ograniczonych do minimum ramach czasowych tego nauczania. Niewątpliwie również przyjęcie neutralistycznego sposobu prezentacji etyki jest łatwiejsze dla nauczyciela tak w przygotowaniu, jak i w przeprowadzeniu wykładu.

Rozważania niniejsze są jednakowoż głosem za nauczaniem zaangażowanym. Zaprezentowano szereg argumentów, natury przede wszystkim metaetycznej, mających uzasadnić taki punkt widzenia w nauczaniu etyki w szkole. Przygotowanie takiego zaangażowanego wykładu jest niewątpliwie wyzwaniem dla uczącego etyki, w którym musi on znaleźć właściwe proporcje między częścią historyczno-opisową a systematyczno-normatywną (by nie stać się ani gawędziarzem, ani ideologiem), dokładnie przemyśleć racjonalność uzasadnień (by nie stać się dogmatykiem). Jest to zadanie trudne, ale warte zachodu, jeśli nauczanie etyki ma ugruntować postawy, w których nie przekreślając wewnętrznej wolności człowieka, nie odrzucając pluralizmu kulturowego i światopoglądowego, promuje się jednak (nie - narzuca) wartości etyczne i postawa odpowiedzialności.

\section{SUMMARY}

This essay is an metaethical reflection on the character of teaching ethics in school and academic realities of Poland. The aim is to show the type of ethics which is the best in achieving the syllabus and educational assumptions of the discipline. It seems that the most important of them are the following issues:

- Rationalization of ethical choices, i.e. giving the reasons for choosing particular moral values

- The clearly presented problem of the responsibility for the decisions

- Strengthening proper improvements of the character, which enable to choose and defend moral values: tolerance, ecological responsibility.

There are two the most general ways distinguished of presentation of ethics within school or academic lecture: the "naturalistic" and the "engaged" one.

The naturalistic approach is restricted to the presentation of various ethical systems without any discussion included on evaluating these systems. The engaged approach critically analyses different ethical solutions, reasonably assessing their character.

Despite the arguments for the naturalistic approach (presently fashionable criticism of ethics, the issue of toleration and avoidance of the ideologisation) I undertake to defend the engaged approach as better at giving possibilities of reasonable criticism of moral behaviors and as the result of this criticism, moral attitudes which are the goal of teaching ethics in school. 